\title{
Chemioterapia dootrzewnowa w raku jajnika
}

\author{
Marcin Śniadecki, Adam Ostrowski, Marcin Liro, Dariusz Grzegorz Wydra
}

Chemioterapia dootrzewnowa (IPC) jest rodzajem leczenia uzupełniającego. Stosuje się ją najczęściej po zabiegu cytoredukcji nowotworu złośliwego. Jej początki sięgają lat 50., kiedy to zaczęto ją stosować w przypadku rozsiewu nowotworowego w jamie brzusznej. Współcześnie stanowi ona jedną z opcji leczniczych w przypadkach wielu nowotworów. W artykule skoncentrowano się na kluczowych zagadnieniach dotyczących IPC oraz dootrzewnowej chemioterapii śródoperacyjnej w hipertermii (HIPEC) w raku jajnika. Przedstawiono aktualny stan wiedzy na temat IPC i HIPEC w tym nowotworze. Omówiono zagadnienia takie jak czas zastosowania IPC, uzasadnienie jej użycia, różnice w stosunku do chemioterapii dożylnej (IVC), podano korzyści i wady, w tym omówiono skuteczność, toksyczność, kwalifikację do terapii oraz wymogi stawiane wobec ośrodka przeprowadzającego taką procedurę medyczną. Zwrócono także uwagę na kwestie finansowe związane z IPC i HIPEC.

\section{Intraperitoneal chemotherapy in ovarian cancer}

Intraperitoneal chemotherapy is a type of adjuvant therapy. It is used most frequently after cytoreduction of a malignancy. Its origins date back to the 1950s, when it began to be applied in cases of cancer dissemination in the abdominal cavity. Today it is one of treatment options in many tumors. This article focuses on key issues relating to IPC and hyperthermic intraoperative peritoneal chemotherapy (HIPEC) in ovarian cancer. The current knowledge about the IPC and HIPEC in this tumor is presented. Issues such as the timing of the IPC, the justification of its use, the differences in comparison to intravenous chemotherapy (IVC) are discussed. Also presented are the advantages and disadvantages, including the efficacy, toxicity, and eligibility for therapy versus the requirements for the institution performing this medical procedure. Financial issues regarding IPC and HIPEC are also discussed.

NOWOTWORY Journal of Oncology 2013; 63, 4: 311-319

Słowa kluczowe: chemioterapia dootrzewnowa, rak jajnika, hipertermia

Key words: intraperitoneal chemotherapy, ovarian cancer, hyperthermia

\section{Wprowadzenie}

Chemioterapia dootrzewnowa (intraperitoneal chemotherapy - IPC) jest znana od 1953 roku. Jednym z pierwszych, który opisał ten rodzaj leczenia, był H.W. Lichtenberg. Użył on sulfonamidu w zapaleniu otrzewnej [1]. W dwa lata po nim A.S. Weisberger wraz z zespołem przedstawił doświadczenia z podawaniem iperytu azotowego u 43 pacjentów z wysiękiem do jam ciała (w tym do jamy otrzewnej), który był spowodowany przez różne nowotwory złośliwe [2]. W badanej grupie 10 pacjentek chorowało na raka jajnika (RJ). U 28 (65\%) chorych po zastosowaniu chemioterapii stwierdzono poprawę wyrażającą się brakiem narastania wodobrzusza. W tej grupie znalazły się wszystkie chore na RJ. Niepowodzenie leczenia dotyczyło 16 (37\%) pacjentów w badaniu, co według autorów wynikało z zaawansowania choroby. Podkreślono wagę zastosowania tego rodzaju chemioterapii w sytuacji, w której choroba nie jest zaawansowana. Mniejszą toksyczność chemioterapeutyku stwierdzono przy podawaniu dootrzewnowym w porównaniu z dożylnym oraz zwrócono uwagę na możliwość zamiennego leczenia innym lekiem - radioaktywnym koloidalnym złotem. Zasugerowano, że połączenie dwóch leków może być sku-

Katedra i Klinika Ginekologii, Ginekologii Onkologicznej i Endokrynologii Ginekologicznej

Gdański Uniwersytet Medyczny 


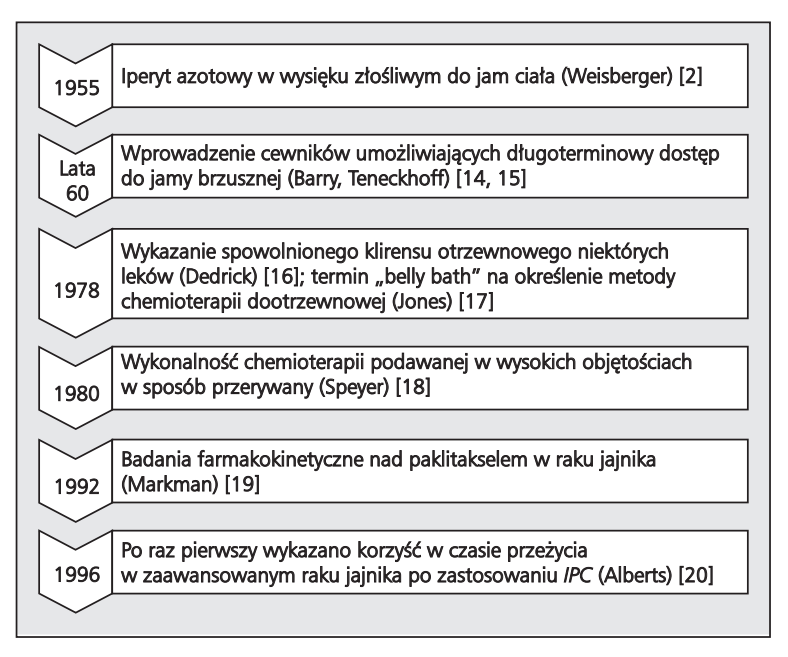

Rycina 1. „Kroki milowe” w chemioterapii dootrzewnowej

teczniejsze niż jednego. Wiele z tych założeń opartych na obserwacjach klinicznych znalazło później potwierdzenie $w$ badaniach z randomizacją [3].

Z punktu widzenia onkologii klinicznej chemioterapię dootrzewnową (IPC) można zaliczyć do terapii adiuwantowych [4], gdyżjest stosowana po operacji mającej na celu uzyskanie maksymalnej redukcji masy komórkowej nowotworu (operacja cytoredukcyjna) $[5,6]$. Może ona także odpowiadać kryteriom leczenia konsolidującego, ponieważ stosuje się ją po uzyskaniu całkowitej odpowiedzi patologicznej [7].

\section{IPC $w$ innych nowotworach niż rak jajnika}

Badania kliniczne nad technikami IPC były prowadzone przez wiele lat u pacjentów z różnymi nowotworami. Zanim zastosowano ją w raku jajnika, IPC była przedmiotem badań w rozsiewie wewnątrzbrzusznym, m.in. z powodu raka jelita grubego (jako dootrzewnowa chemioterapia perfuzyjna w hipertermii (hyperthermic intraperitoneal chemotherapy — HIPEC) [6], raka wyrostka robaczkowego [8], raka żołądka [9], a ponadto jako izolowana chemioterapia w hipertermii w czerniaku i mięsakach tkanek miękkich [10-13]. Na rycinie 1 przedstawiono "kroki milowe" chemioterapii dootrzewnowej, które doprowadziły w końcu do wypróbowania jej z powodzeniem w raku jajnika $[2,14-20]$.

\section{Znaczenie operacji i chemioterapii drogą dootrzewnową $w \mathbf{R J}$}

Przeprowadzenie optymalnej cytoredukcji ma podstawowe znaczenie w rokowaniu pacjentek z RJ, bowiem skuteczność chemioterapii jest pochodną leczenia chirurgicznego. Najczęściej pod terminem „optymalna cytoredukcja” rozumie się usunięcie wszystkich widocznych zmian nowotworowych z ewentualnością pozostawienia wszczepów najwyżej o średnicy $1 \mathrm{~cm}[20,21]$. Nie jest to jedyny czynnik rokowniczy, gdyż na szanse wieloletniego przeżycia składa się wiele czynników — wśród nich najważniejsze są: odpowiedni dobór pacjentek, lokalizacja zmian i doświadczenie ginekologa-onkologa.

Hamilton i Berek przedstawili listę cech dotyczących guza oraz działania leku, aby IPC była skuteczna (ryc. 2) [5]. Chociaż stosowanie IPC $w$ I rzucie leczenia nie jest jeszcze alternatywą wobec chemioterapii i.v. we wczesnym RJ, leczenie to zajmuje obecnie trwałe miejsce wśród opcji terapeutycznych u pacjentek w stadium IIIC pierwotnego raka, które zostały optymalnie zoperowane. Tabela I przedstawia czynniki brane pod uwagę w selekcji pacjentek do zastosowania IPC [22].

Stosowanie IPC w raku jajnika można poddać ocenie w kilku kategoriach: efektywności, zwłaszcza porównując ją z innymi dostępnymi opcjami leczenia, pod względem powikłań, jakości życia oraz kosztów związanych z leczeniem.

\section{Skuteczność}

Skuteczność kliniczna w pierwotnym RJ w pierwszej linii leczenia była przedmiotem 8 badań z randomizacją. Przegląd systematyczny tych badań z 2011 roku [23] zademonstrował przewagę chemioterapii dootrzewnowej nad dożylną. Najważniejsze punkty badań, które wzięto pod uwagę, zamieszczono w tabeli Il. Korzyść z IPC mieściła się w przedziale średnio od 6 do 16 miesięcy całkowitego przeżycia w różnych stadiach zaawansowania RJ. Pierwszym, które wykazało wyższą skuteczność i większe bezpieczeństwo stosowania IPC w porównaniu do chemioterapii dożylnej, było badanie Albertsa i wsp. [20]. W tym badaniu ryzyko względne zgonu pacjentek poddanych IPC było niższe w porównaniu z tymi, których nie leczono za pomocą IPC. W nielicznych badaniach (Kirmani i wsp. [24] oraz Yen i wsp. [25]) wyniki niekorzystnie wskazywały na IPC jako metodę leczenia I rzutu. Pozostałe badania o różnej liczbie chorych pokazywały takie same lub korzystne wyniki leczenia IPC w porównaniu do chemioterapii i.v. [3, 20, 26-30].

Wykazanie zysku terapeutycznego u pacjentek poddanych IPC znalazło swoje odzwierciedlenie w opracowaniach i wytycznych amerykańskiego Narodowego Instytutu Raka (National Cancer Institute - NCl) oraz National Comprehensive Cancer Network (NCCN), według których IPC jako metodę leczenia uzupełniającego I rzutu zaleca się w stadiach II-IV. NCCN jako jedną z opcji leczenia podaje możliwość zastosowania paklitakselu w schemacie dose-dense ( 6 cykli po $80 \mathrm{mg} / \mathrm{m}^{2}$ paklitakselu i.v. i karboplatyna z AUC 6 w jednogodzinnych wlewach dożylnych w dniach 1., 8. i 15.) [31-33].

Podstawowym czynnikiem wpływającym na rokowanie w RJ jest zakres cytoredukcji, chociaż inne czynniki, takie jak np. pochodzenie histopatologiczne rozsiewu nowotworowego czy stadium zaawansowania mogą także mieć istotny wpływ na rokowanie [6, 9,22,34]. Do tej pory wykazano skuteczność kliniczną cyklofosfamidu [35], cisplatyny [20, 36], karboplatyny [27, 36], paklitakselu [19], docetakselu 


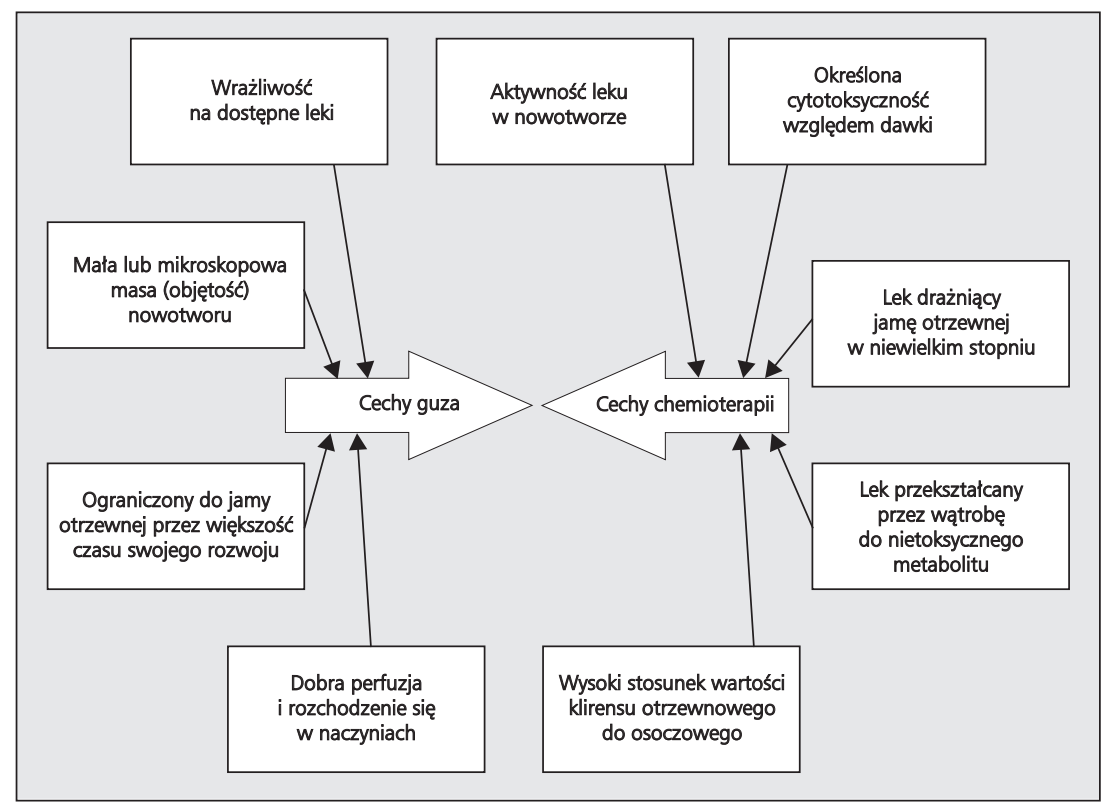

Rycina 2. Wymagania stawiane wobec guza i chemioterapii, jakie muszą być spełnione, aby chemioterapia była skuteczna (wg Hamilton, Berek, 2006) [5]

Tabela I. Czynniki, które wpływają na decyzję o wszczepieniu cewnika dootrzewnowego i zastosowaniu chemioterapii dootrzewnowej (IPC) [22]

\begin{tabular}{ll} 
Właściwe stadium choroby & Niezaawansowane (FIGO I-III) \\
$\begin{array}{l}\text { Skuteczna (optymalna) cytoredukcja } \\
\text { Przewidywana dobra tolerancja chorej na zakładaną ilość cykli } 0,25 \mathrm{~cm} \\
\text { chemioterapii }\end{array}$ & Dobry stan ogólny \\
$\begin{array}{l}\text { Nie przeprowadzono dużych resekcji jelitowych } \\
\text { Możliwość umiejscowienia systemu port-cewnik w odpowiednim } \\
\text { miejscu }\end{array}$ & Operacja z ograniczonym udziałem jelita \\
$\begin{array}{l}\text { Przewidywana dobra tolerancja na dużą objętość płynu podanego } \\
\text { do jamy otrzewnej i jego adekwatna dystrybucja }\end{array}$ & $\begin{array}{l}\text { Pacjentka niepoddana wielokrotnym operacjom, nieoperowana } \\
\text { z przyczyn zapalnych, po wcześniejszym leczeniu dootrzewnowym }\end{array}$ \\
$\begin{array}{l}\text { Możliwość monitorowania efektów leczenia i pielęgnacji cewnika } \\
\text { (portu) }\end{array}$ & Doświadczony ośrodek z infrastrukturą leczniczą oddziału chemioterapii \\
\hline
\end{tabular}

[37]. Wprowadzenie do leczenia pochodnych platyny, a później taksanów było ważnym krokiem w IPC. Potwierdziła to ostatecznie metaanaliza naukowców z grupy Cochrane [38]. Niektóre z tych leków chętnie są podawane drogą dojamową z uwagi na ich dużą toksyczność ogólną przy podawaniu dożylnym. Z tego powodu wśród pochodnych platyny stosowana jest karboplatyna. Gorsza penetracja do guza przy odpowiadających sobie stężeniach obu pochodnych platyny u szczurów nie znalazła odzwierciedlenia w wynikach leczenia u ludzi. W badaniu du Bois i wsp. porównano dwie grupy pacjentek poddawane schematowi dożylnemu: cisplatyna/paklitaksel lub karboplatyna/paklitaksel. Nie różniły się one pod względem udziału przeżyć całkowitych ani pod względem czasu do wznowy. Grupy różniły się natomiast pod względem jakości życia pacjentek i profilem toksyczności chemioterapeutyków (większa toksyczność hematologiczna przy mniejszej toksyczności neurologicznej i gastroeneterologicznej karboplatyny) [39, 40].
W onkologii istnieje zasada, że jeżeli możliwe jest dotarcie bezpośrednio do kompartmentu lub regionu objętego chorobą, to należy to uczynić. Jeżeli zaś choroba ma charakter rozsiany, należy stosować leczenie ogólne. To samo ma zastosowanie w leczeniu operacyjnym i koncepcji chemioterapii w raku jajnika. Gdyby możliwe było usunięcie mikrosiedlisk nowotworu po usunięciu wszystkich widocznych ognisk nowotworu, chemioterapia mogłaby nie być potrzebna. Rak jajnika nie jest najczęściej chorobą systemową i ograniczony jest do przedziału, którym - w jego przypadku — jest powierzchnia otrzewnej [41]. Resekcja doszczętna $(R=0)$ w raku jajnika byłaby więc równoznaczna z całkowitą peritonektomią z wycięciem otrzewnej przepony i otrzewnej jelitowej, co mogłoby potencjalnie wykluczyć konieczność leczenia chemicznego [42, 43]. Chemioterapia dootrzewnowa wydaje się być kompromisem pomiędzy nieradykalną ( $w$ rozumieniu teorii kompartmentów oraz $z$ definicji) operacją cytoredukcyjną a koniecznością lecze- 
Tabela II. Podsumowanie dotychczasowych badań z randomizacją nt IPC

\begin{tabular}{|c|c|c|c|c|c|c|}
\hline Autorzy & $\begin{array}{l}\text { Rok } \\
\text { publikacji }\end{array}$ & Grupa chorych & Schemat chemioterapii & $\begin{array}{l}\text { Wynik przeżycia } \\
\text { (w miesiącach) }\end{array}$ & Wnioski & $\begin{array}{l}\text { Pozycja } \\
\text { piśmiennictwa }\end{array}$ \\
\hline Zybelberg i wsp. & 1986 & 20 & $\begin{array}{l}10 \times(4 \mathrm{w}) \text { ADM } 35 \mathrm{mg} / \mathrm{m}^{2}+\mathrm{VLB} 10 \mathrm{mg} / \mathrm{m}^{2}+5-\mathrm{FU} \\
750 \mathrm{mg} / \mathrm{m}^{2}+\text { IFO } 1 \mathrm{~g} / \mathrm{m}^{2}+\mathrm{BL} 15 \mathrm{mg} / \mathrm{m}^{2}+\mathrm{CCDP} \\
100 \mathrm{mg} / \mathrm{m}^{2} \text { i.v. }(1) \mathrm{vs} \text { ADM } 20 \mathrm{mg} / \mathrm{m}^{2}+30 \mathrm{mg} / \mathrm{m}^{2}+\mathrm{VLB} \\
10 \mathrm{mg} / \mathrm{m}^{2}(+0)+0+980215 \mathrm{mg} / \mathrm{m}^{2} \mathrm{BL}+5-\mathrm{FU} \\
500 \mathrm{mg} / \mathrm{m}^{2}+500 \mathrm{mg} / \mathrm{m}^{2}+\text { IFO } 1 \mathrm{~g} / \mathrm{m}^{2}(+0)+\mathrm{CCDPP} \\
50 \mathrm{mg} / \mathrm{m}^{2}+50 \mathrm{mg} / \mathrm{m}^{2} \text { i.v. + i.p. (2) }\end{array}$ & $\begin{array}{l}\text { (1) } 5 \mathrm{Y}-\mathrm{OS} \\
50 \% \\
\text { (2) } 5 \mathrm{Y}-\mathrm{OS} 90 \%\end{array}$ & $\begin{array}{l}\text { IV+IP dało statystycznie lepszy wynik }(\mathrm{p}<0,05) \\
\text { niż samo IV, ale należy dalej zbadać samo } \\
\text { leczenie IP vs IV+IP }\end{array}$ & 26 \\
\hline Kirmani i wsp. & 1994 & $\begin{array}{l}62 \text { chorych w stadium IIc-IV } \\
\text { z chorobą resztkową } \\
(>\text { lub }< \\
\text { lub }=1 \mathrm{~cm}\end{array}$ & $\begin{array}{l}\text { 6x (4w) CCDP } 200 \mathrm{mg} / \mathrm{m}^{2} \text { i.p. + VP } \\
350 \mathrm{mg} / \mathrm{m}^{2} \text { i.p. }+ \text { thiosulfate (1) } \\
\text { vs } 6 \times(3 \mathrm{w}) \text { CCDP } 100 \mathrm{mg} / \mathrm{m}^{2} \text { i.v. }+ \text { CTX } 600 \mathrm{mg} / \mathrm{m}^{2} \text { i.v. }\end{array}$ & $\begin{array}{l}\text { OS? } \\
\text { PFS (w grupie z progresją) } \\
12 \text { (1) vs } 14 \text { (2) }\end{array}$ & $\begin{array}{l}\text { Bez różnic w odsetkach odpowiedzi między (1) } \\
\text { i (2) u pacjentek z ch. resztkową } \leq 1 \mathrm{~cm} \text {, ale nie } \\
\text { wszyscy pacjenci przeszli zakładany plan leczenia }\end{array}$ & 24 \\
\hline Alberts i wsp. & 1996 & $\begin{array}{l}546 \text { chorych z RJ w stadium III } \\
\text { po } \mathrm{cr}=/<2 \mathrm{~cm}\end{array}$ & $\begin{array}{l}6 \times\left(3 \text { tyg.) CTX } 600 \mathrm{mg} / \mathrm{m}^{2} \text { i.v. + CDDP } 100 \mathrm{mg}-2 \text { i.p. (1) }\right. \\
\text { lub i.v. (2) }\end{array}$ & $\begin{array}{l}\text { OS } 49 \text { (1) wobec } 41 \text { (2) } \\
\text { PFS - nie określono }\end{array}$ & $\begin{array}{l}\text { Poprawa przeżycia przy mniejszej toksyczności } \\
\text { drogą i.p. }\end{array}$ & 20 \\
\hline Polyzos i wsp. & 1999 & $\begin{array}{l}90 \text { chorych z RJ w stadium III } \\
\text { po } \mathrm{cr}=/<2 \mathrm{~cm} \mathrm{lub}>2 \mathrm{~cm}\end{array}$ & $\begin{array}{l}6 \times\left(3-4 \text { w.) CBP } 350 \mathrm{mg} / \mathrm{m}^{2} \text { i.v. (1) lub i.p. (2) + CTX }\right. \\
600 \mathrm{mg} / \mathrm{m}^{2} \text { i.v. }\end{array}$ & $\begin{array}{l}\text { OS } 25 \text { (1) i } 26(2) \\
\text { PFS } 19 \text { (1) i } 18 \text { (2) }\end{array}$ & $\begin{array}{l}\text { Korzystniejszy profil toksyczności CBP drogą i.p. } \\
\text { nad i.v. }\end{array}$ & 27 \\
\hline Gaducci i wsp. & 2000 & $\begin{array}{l}113 \text { chorych w stadium II-IV } \\
\mathrm{z} \text { chorobą resztkową }<2 \mathrm{~cm}\end{array}$ & $\begin{array}{l}6 \times(4 \mathrm{w}) \text { CCDP } 50 \mathrm{mg} / \mathrm{m}^{2} \text { i.p. + EPIDOX } \\
60 \mathrm{mg} / \mathrm{m}^{2} \text { i.v. }+600 \mathrm{mg} / \mathrm{m}^{2} \text { CTX i.v. (1) lub CDDP } \\
50 \mathrm{mg} / \mathrm{m}^{2} \text { i.v. + EPIDOX } 60 \mathrm{mg} \text { i.v. + CTX } 600 \mathrm{mg} / \mathrm{m}^{2} \text { i.v. }\end{array}$ & $\begin{array}{l}\text { OS } 67 \text { (1) vs } 51 \text { (2) } \\
\text { PFS } 42 \text { (1) vs } 25 \text { (2) }\end{array}$ & $\begin{array}{l}\text { Korzyść wyrażona OS i PFS była nieznacząca } \\
\text { Bez różnicy w odsetku pCR w second-look } \\
\text { i toksyczności }\end{array}$ & 28 \\
\hline Markman i wsp. & 2001 & 462 & $\begin{array}{l}6 \times(3 \mathrm{w}) \text { PC } 135 \mathrm{mg} / \mathrm{m}^{2} \text { i.v. + CCDP } \\
75 \mathrm{mg} / \mathrm{m}^{2} \text { i.v. (1) lub } 2 \times(4 \mathrm{w}) \text { CBP AUC9 }+6 \times(3 \mathrm{w}) \mathrm{PC} \\
135 \mathrm{mg} / \text { i.v. + CCDP } 100 \mathrm{mg} / \mathrm{m}^{2} \text { i.p. (2) }\end{array}$ & $\begin{array}{l}\text { PFS } 22 \text { (1) vs } 28(2) \\
\text { OS } 52 \text { (1) vs } 63(2)\end{array}$ & $\begin{array}{l}\text { Większość pacjentów nie ukończyła protokołu } \\
\text { (2), duża toksyczność, nie zarekomendowano } \\
\text { schematu }\end{array}$ & 29 \\
\hline Yen i wsp. & 2001 & $\begin{array}{l}132 \text { chorych z RJ w stadium III } \\
<1 \mathrm{~cm}\end{array}$ & $\begin{array}{l}6 \times(3 w) \text { CCDP } 100 \mathrm{mg} / \mathrm{m}^{2} \text { i.p. (1) } \\
\text { vs } 50 \mathrm{mg} / \mathrm{m}^{2} \text { i.v. (2) }\end{array}$ & OS 43 (1) vs 48 (2) & $\begin{array}{l}\text { Niższa toksyczność IPC, bez znamiennej różnicy } \\
\text { w czasie przeżycia }\end{array}$ & 25 \\
\hline Young i wsp. & 2003 & $\begin{array}{l}251 \text { chorych w stadium I ill, } \\
\mathrm{R}=0 \mathrm{~cm}\end{array}$ & $32 \mathrm{P}(1)$ vs $\mathrm{CP}(2)$ & $\begin{array}{l}\text { Częstość wznów } \\
\text { po } 10 \text { latach: } \\
35 \% \text { (1) vs } 28 \% \text { (2) }\end{array}$ & Niższa częstość wznów przy terapii CP & 30 \\
\hline $\begin{array}{l}\text { Armstrong i wsp. } \\
\text { (GOG 172) }\end{array}$ & 2006 & $\begin{array}{l}492 \text { chore } w \text { stadium III RJ } \\
\text { lub } P R O, R=<1 \mathrm{~cm}\end{array}$ & $\begin{array}{l}\text { (d1) PC } 135 \mathrm{mg} / \mathrm{m}^{2} \text { i.v. + (d2) CCDP } 75 \mathrm{mg} / \mathrm{m}^{2} \text { i.v. (1) vs } \\
\text { (d1) PC } 135 \mathrm{mg} / \mathrm{m}^{2} \text { i.v. + (d2) CCDP } 100 \mathrm{mg} / \mathrm{m}^{2} \text { i.p. + (d8) } \\
\text { PC } 60 \mathrm{mg} / \mathrm{m}^{2} \text { i.p. (2) }\end{array}$ & $\begin{array}{l}\text { PFS } 18,3 \text { (1) vs } 23,8(2) \\
\text { OS } 49,7 \text { (1) vs } 65,5 \text { (2) }\end{array}$ & $\begin{array}{l}\text { Gorsza jakość życia w (2), ale tylko do jednego } \\
\text { roku od początku terapii }\end{array}$ & 3 \\
\hline
\end{tabular}

Objaśnienia skrótów: PFS (progression free surviva) — przeżycie wolne od wznowy; OS (overall survival) — przeżycie całkowite; ADM — doksorubicyna; VBL — winka-leukoblastyna; BL — bleomycyna; 5-FU — 5-fluorouracyl; IFO - ifosfamid;

CTX - cyklofosfamid; CDDP - cisplatyna; CBP - karboplatyna; VP - etopozyd; $32 \mathrm{P}$ - fosforan chromu; CP - terapia cyklofosfamid-cisplatyna; PRO - pierwotny rak otrzewnej; PC - paklitaksel; (3w) - co trzy tygodnie; (4w) - co cztery tygodnie; 


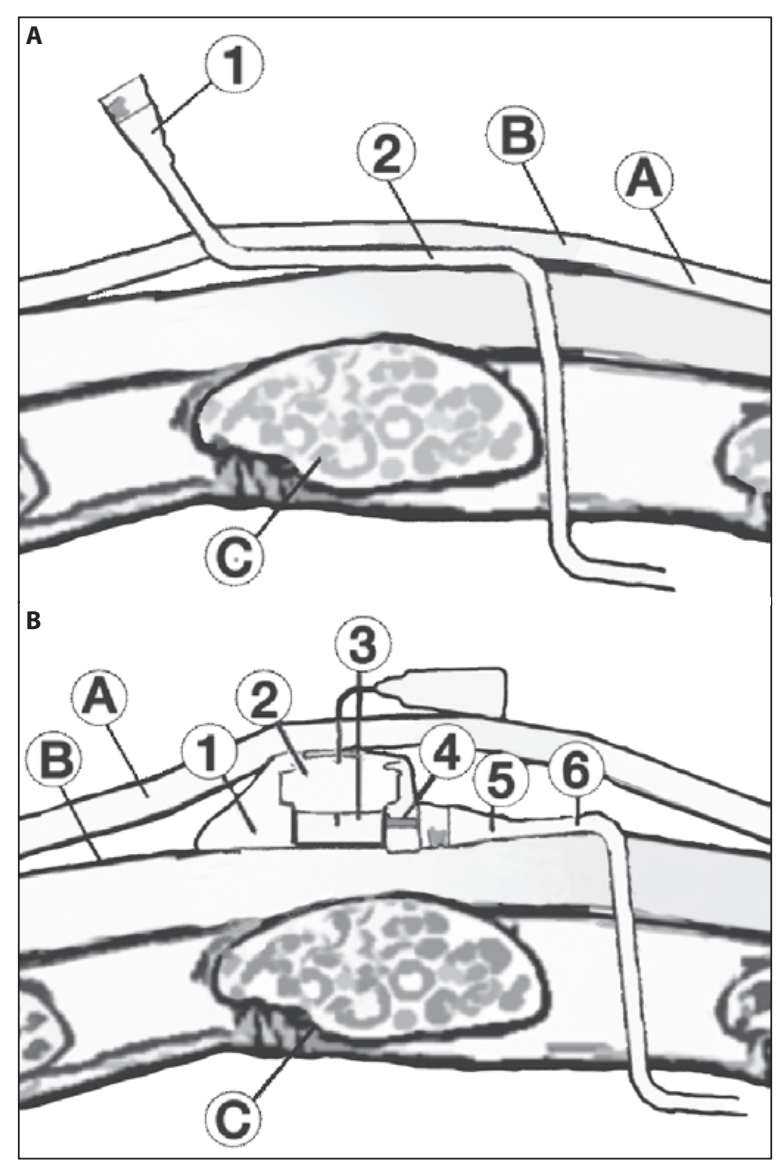

Rycina 3. Schemat cewników dootrzewnowych: A. historyczny cewnik Tenckhoffa, B. system port-cewnik. Legenda: A — skóra; B — mięsień; C - żebro; A. 1 - początek drenu; 2 - rurka drenu; B. 1 - obudowa portu; 2 - przegroda samouszczelniająca się; 3 - miejsce wkłucia igły Hubera; 4 - nasuwka; 5, -dren; 6 - mankiet

nia onkologicznego w tej szczególnej sytuacji. Całkowita głębokość penetracji leku dootrzewnowego wynosi $3 \mathrm{~mm}$, dlatego wydaje się, iż największy guzek, jaki można zostawić, nie powinien być większy niż 2,5 mm (różnica wynika z "kapsuły" z tkanki włóknistej, która pokrywa guzek) [44].

\section{Rodzaje cewników i technika implantacji}

W chemioterapii dootrzewnowej stosuje się całkowicie wszczepialne tytanowe lub plastikowe porty żylne (FIPADs - fully implanted peritoneal access devices), które otwierają się do jamy brzusznej silikonowym lub poliuretanowym cewnikiem (ryc. 3). Cewniki dootrzewnowe Tenckhoffa i jego modyfikacje wyszły z użycia [15]. Port można wszczepić zarówno techniką klasyczną, jak i laparoskopową podczas operacji cytoredukcyjnej lub przy kolejnym zabiegu.

\section{Powikłania}

Cewniki dootrzewnowe, przez które podawano chemioterapię, wyszły z użycia z powodu braku objęcia przez chemioterapeutyk całej jamy brzusznej (min. przez powstawanie przegród łącznotkankowych) oraz niewygodę ich
Tabela III. Powikłania chemioterapii dootrzewnowej [47]

\begin{tabular}{lc}
\hline Rodzaj powikłania & Częstość (\%) \\
\hline Ból & $2,3-85,7$ \\
Zablokowanie cewnika & $2,1-22$ \\
Zakażenie & $0-20,5$ \\
Nieszczelność systemu & $0-11,9$ \\
Trudność w uzyskaniu dostępu & $0-11,1$ \\
Zapalenie otrzewnej & $0-8,3$ \\
Cofnięcie się portu & $1,8-5,3$ \\
Uszkodzenie jelita & $0-3,6$ \\
\hline
\end{tabular}

stosowania. Systemy port-cewnik również nie pozwalają na całkowite uniknięcie problemów z należytym objęciem jamy brzusznej działaniem chemioterapeutyku. Powikłania są udziałem 6,8-40,5\% pacjentek i mogą być przyczyną przerwania chemioterapii dootrzewnowej u 10-34\% chorych [45-47]. Tabela III przedstawia rodzaj i częstość powikłań na podstawie opracowania Helma [47]. Powikłania chemioterapii związane z systemem port-cewnik mogą stanowić znaczny odsetek przyczyn przedwczesnego ukończenia chemioterapii. Najczęstszymi powodami przerwania IPC są zakażenia i zablokowanie cewnika [47]. Robinson i Beyer podali odsetek pacjentek z pierwotnym RJ, które ukończyły planowaną liczbę cykli, wynoszący $68,8 \%$, a w przypadku nawrotowego RJ wynosił on 38\%. Autorzy podali zablokowanie systemu do IPC jako najczęstszą przyczynę przedwczesnego ukończenia leczenia [48]. Do innych częstszych przyczyn należą: zapalenie otrzewnej i perforacja jelita $(1,3-3,6 \%)[47,49]$. Milczek i wsp. zaobserwowali, że przy wszczepianiu, jak i usuwaniu cewnika dootrzewnowego najczęściej występuje uszkodzenie jelita [50]. W dwóch przypadkach skutkowało to przerwaniem leczenia. Wydaje się jednak, że powikłania mogły zależeć od rodzaju cewników (cewniki Tenckhoffa), co potwierdzają też inne prace $[49,51]$, oraz faktu wtórnych operacji cytoredukcyjnych, w trakcie których cewniki były wszczepiane. Fakt pierwotnej lub wtórnej operacji nie wpływa jednak na odsetki ukończonych kursów chemioterapii $[45,48,51]$. Implantowanie systemu podczas operacji jelitowej nie musi wpływać na zwiększenie odsetka zakażeń. Unikanie wszczepiania systemu podczas operacji jelitowych nie jest równoznaczne z uniknięciem ryzyka perforacji, która może wystąpić nawet po 36 miesiącach [51,52]. Do pozostałych powikłań należą: ból o różnym nasileniu lub dyskomfort w jamie brzusznej (o charakterze najczęściej przemijającym, może być silniejszy w czasie wlewu leku), przetoka pochwowa, erozja portu, nieszczelność systemu, trudność w uzyskaniu dostępu do podawania chemioterapii $[47,53]$. Umieszczenie portu na brzegu najniższego żebra łuku żebrowego i jego przymocowanie do powięzi powinno zapobiec problemom z odczepianiem się lub przemieszczaniem portu oraz będzie komfortowe dla pacjenta i wygodne dla 
personelu leczącego. Preferencje co do rodzajów systemów (producentów) w odniesieniu do powikłań mogą nie mieć znaczenia w rękach doświadczonego ginekologa-onkologa. Wydaje się, że sposobami uniknięcia najczęstszych powikłań mogących skutkować przerwaniem chemioterapii IP są: stosowanie tego leczenia przy dobrym stanie ogólnym pacjentki i po uzyskaniu optymalnej cytoredukcji, rygorystyczne stosowanie się do zasad aseptyki i antyseptyki (również po implantacji - podczas cykli chemioterapii), ostrożność w doborze miejsc implantacji portu i wprowadzenia cewnika (pewne umocowanie systemu i sprawdzenie poprawności jego założenia, na przykład poprzez podanie uropoliny pod kontrolą skopii rentgenowskiej). Odpowiedni odstęp od zabiegu do wdrożenia chemioterapii może mieć znaczenie w przypadku użycia w przyszłości bevacizumabu i innych chemioterapeutyków hamujących angiogenezę w schematach IPC, zwłaszcza w odniesieniu do ryzyka nieszczelności zespoleń jelitowych. Pokazują to wyniki badań w zaawansowanym raku jelita grubego u pacjentów po resekcjach jelita grubego [54,55]. W ośrodku autorów przeprowadzanie IPC zaczyna się po otrzymaniu wyniku histopatologicznego z operacji cytoredukcyjnej, w której wykonano kompletny staging. Na ryzyko powikłań ma również wpływ doświadczenie zespołu leczącego. Zaobserwowano, że po okresie 4 lat można stwierdzić znaczący spadek odsetka powikłań [48].

\section{Jakość życia}

Wpływ IPC na jakość życia jest niekorzystny, lecz ogranicza się on do jednego roku po zakończonym leczeniu [3]. Jakość życia przekłada się na czas przeżycia. W jednym z badań oceniających jakość życia pacjentek biorących udział w badaniu GOG-172 (Gynecologic Oncology Group-172) wykazano, że chore odczuwające pogorszenie jakości życia, zwłaszcza w aspekcie fizycznym, żyły krócej [56].

\section{Toksyczność}

Toksyczność IPC jest znaczna. W badaniu NCl [31] 42\% chorych otrzymało wszystkie 6 planowanych cykli chemioterapii, podobnie jak w badaniu GOG-172 [45]. Najpoważniejszymi powikłaniami chemioterapii były: ciężkie znużenie (fatigue), ból, a także powikłania hematologiczne, gastroenterologiczne, metaboliczne lub neurologiczne [31]. Wydaje się, że niektóre schematy leczenia mogą mieć niższy (lepiej tolerowany) poziom toksyczności.W jednym zostatnich badań retrospektywnych z użyciem schematu GOG-172 (paklitaksel $135 \mathrm{mg} / \mathrm{m}^{2}$ i.v. we wlewie 24-godzinnym w pierwszym dniu, cisplatyna $100 \mathrm{mg} / \mathrm{m}^{2}$ i.v. w drugim dniu, paklitaksel $60 \mathrm{mg} / \mathrm{m}^{2}$ i.p. wósmym dniu w 6 cyklach co 3 tygodnie) uzyskano odsetek ukończonych wszystkich cykli wynoszący 83\% [57].

\section{Rachunek koszt-efektywność}

Badania, w których brana jest pod uwagę ocena kosztów związanych z leczeniem, nabierają nowego znaczenia w kon- tekście kryzysu ekonomicznego. Rachunek kosztów i efektywności IPC w raku jajnika był przedmiotem analiz w trzech dużych badaniach. W jednym z nich Bristow i wsp. porównali: 1) podawanie paklitakselu i.v. (we wlewie $24 \mathrm{~h}$ ) w schemacie z cisplatyną i.p. w warunkach klinicznych oraz z paklitakselem i.p. w warunkach ambulatoryjnych (schemat i.p./i.v.); 2) podawanie paklitakselu (we wlewie $3 \mathrm{~h}$ ) z karboplatyną i.v. ambulatoryjnie (schemat i.v./i.v.).W schemacie chemioterapii i.p./i.v., biorąc pod uwagę wskaźnik QALY (qualiity adjusted life years), uzyskano niski zysk zdrowotny $(0,56)$ dla jednej pacjentki przy wysokim wydatku, wynoszącym 21039 dolarów [58]. W innym badaniu ci sami autorzy przeprowadzili rachunek kosztów i efektywności, wykazując różnicę jakości w QALY przez porównanie ośrodka „eksperckiego" (takiego, który wykonuje > 75\% optymalnych cytoredukcji i prowadzi IPC) z ośrodkiem o niższym standardzie. Badania dowiodły lepszej efektywności zdrowotnej ośrodka „eksperckiego" przy niższym wydatkowaniu pieniędzy, o czym świadczy mierzony i porównywany w obu przypadkach parametr QALY (2,78 przy 10695 dolarów wobec 2,33 przy 39957 dolarów) [59]. Harlivesky i wsp., badając całkowite przeżycia i toksyczność stopnia 3. i 4., wykazali większy koszt (w przeliczeniu na QALY) dla chemioterapii i.p. z udziałem cisplatyny i paklitakselu w porównaniu z chemioterapią i.v. opartą na karboplatynie i paklitakselu podawanych w trybie ambulatoryjnym w 7. roku od włączenia leczenia [60]. We wszystkich badaniach podkreślano konieczność rozwoju chemioterapii w kierunku lepszego profilu bezpieczeństwa przy tej samej skuteczności, np. poprzez stosowanie schematów i dawek możliwych do stosowania ambulatoryjnie.

\section{Dootrzewnowa chemioterapia perfuzyjna w hipertermii (HIPEC) w raku jajnika}

Istotą hipertermii jest wywarcie dodatkowego efektu cytotoksycznego poprzez działanie energii cieplnej. Wiadomo jednak, że hipertermia jest nie tylko środowiskiem, w którym leki cytotoksyczne działają skuteczniej, ale sama wywołuje zmiany w środowisku komórek nowotworowych poprzez pobudzenie układu immunologicznego, rozpuszczanie podwójnej warstwy lipidowej, podnoszenie metabolizmu czy przez zwolnienie lub zatrzymanie replikacji w fazie S [61].

Do tej pory korzyść z leczenia napromienianiem w połączeniu z leczeniem chemicznym w warunkach hipertermii o poziomie dowodu 1 i rekomendacjach klasy A, wykazano w nielicznych badaniach, w szczególnych przypadkach w kilku typach nowotworów, m.in. w zaawansowanym raku szyjki macicy, gdzie wykazano wzrost odsetka całkowitych wyleczeń i udziału przeżyć 3-letnich) [62,63], a także w nawrotowym raku piersi - przede wszystkim w sytuacji ponownego napromieniania (zwiększenie częstości całkowitej regresji miejscowej - zwłaszcza w przypadku nawrotów mniejszych niż $30 \mathrm{~mm}$ ) [64, 65].

W raku jajnika HIPEC jest przykładem miejscowego stosowania energii cieplnej do $40-43^{\circ} \mathrm{C}$, poprzez podgrzewanie 
płynów cyrkulujących w obiegu jama brzuszna-pompa-jama brzuszna, w których rozpuszczony jest chemioterapeutyk. Stosuje się ją w badaniach eksperymentalnych u wybranych pacjentek z pierwotnym, nawrotowym lub chemioopornym $\mathrm{RJ}$ jako leczenie uzupełniające do zabiegu cytoredukcyjnego oraz jako leczenie konsolidujące lub neoadiuwantowe. Kandydatkami są chore, u których rozsiew nowotworowy pozwala na wykonanie operacji z pozostawieniem małych zmian, tj. do 2,5-5 mm (CCS 0-2) [66]. Doszczętność operacji zmniejszającej masę nowotworu oprócz stadium zaawansowania choroby jest podstawowym czynnikiem rokowniczym u pacjentek kwalifikowanych do HIPEC. Dobrą korelację z obrazem śródoperacyjnym wykazuje badanie PET/CT, co nabiera znaczenia w kwalifikacji przedoperacyjnej chorych do tej procedury, pozwalając przewidzieć doszczętność resekcji [67]. Pacjentki właściwie zakwalifikowane mogą odnieść korzyści z HIPEC, osiągając kilkuletnie przeżycia. Wyniki dotychczasowych badań są różne. W metaanalizie przeprowadzonej przez Doverna i wsp. obejmującej 16 badań z udziałem 546 pacjentek z pierwotnym zaawansowanym (stadium III-IV), przetrwałym lub nawrotowym RJ z rozsiewem do otrzewnej, które zostały poddane operacji cytoredukcyjnej i HIPEC wykazano, że średnia lub mediana przeżycia wynosi od 19 do 71,1 miesiąca. Pięcioletni odsetek przeżyć waha się od 15,0 do 63,4, a śmiertelność w badanej grupie wynosi do 10,5\%, przy śmiertelności pooperacyjnej wynoszącej 2,9\%. Powikłania pooperacyjne po HIPEC dotyczą 34,5\% chorych [68]. W badanej grupie chorych ponownych interwencji wykonano 21 u 476 pacjentek (4,4\%). W uwzględnionej w tej metaanalizie pracy Cotte'a i wsp., w najliczniejszej grupie chorych stwierdzono najdłuższą medianę przeżycia wynoszącą 54,9 miesiąca [69]. Potwierdza to fakt, że agresywne leczenie mające na celu uzyskanie maksymalnej cytoredukcji pozwala uzyskać najlepsze rokowanie przy względnie niskim odsetku poważnych powikłań. Glockzin i wsp., którzy szczególnie skoncentrowali się na powikłaniach chirurgicznych podczas operacji na wątrobie przy HIPEC, stwierdzili łączny odsetek powikłań wynoszący 70\% [70]. U 33\% pacjentów w tym badaniu wystąpiły: ostre zapalenie trzustki, ropień lub wyciek chłonki. Obecnie jednak brak jest jeszcze standardów postępowania co do stosowania HIPEC. Jednym z dodatkowych, w porównaniu z chemioterapią przepływową bez zwiększonej temperatury, wciąż nierozwiązanym problemem, jest rozchodzenie się temperatury we wszystkie miejsca na odpowiednim poziomie oraz jej kontrola [71].

\section{Perspektywy leczenia dootrzewnowego w raku jajnika}

W fazie badań klinicznych znajdują się obecnie nowe leki, np. biologiczne, takie jak catuksomab [72]. Na uwagę zasługują także badania eksperymentalne. Jednym z nich jest próba zastąpienia zwiększenia temperatury przez podanie roztworu adrenaliny do jamy brzusznej. Ma to na celu poprawę skuteczności działania leków poprzez przedłużenie ich działania w guzie oraz zmniejszenie odsetka powikłań ogólnych związanych z IPC (wolniejsze wchłanianie leku z jamy brzusznej) [73]. Na modelu rozsiewu nowotworowego u szczurów wykazano trzykrotny wzrost stężenia cisplatyny w guzie (podawanej w dawce $30 \mathrm{mg} / \mathrm{L}$ ) z adrenaliną w normotermii w porównaniu z grupą kontrolną bez adrenaliny w normotermii oraz w grupie bez adrenaliny, ale w hipertermii $\left(42^{\circ} \mathrm{C}\right)$. Stężenie leku w grupie $z$ adrenaliną w normotermii było wyższe także w mięśniach wyściełających jamę otrzewnej, a mniejsze w nerkach i mięśniach klatki piersiowej w porównaniu z grupami bez podania adrenaliny. Sama technika sposobu dostarczania chemioterapii również ulega zmianom, otwierając nowe możliwości podawania chemioterapii dootrzewnowej [74]. Koncepcja chemioterapii dootrzewnowej wciąż się rozwija, a dowodem tego są badania kliniczne oceniające możliwość zastąpienia leczenia chirurgicznego I rzutu w zaawansowanym raku jajnika [75].

\section{Podsumowanie}

Rosnący udział chemioterapii dootrzewnowej w leczeniu pacjentek z rakiem jajnika może sugerować odniesienie okołooperacyjnych korzyści w zastosowaniu jej przed operacją, podobnie jak w przypadku neoadiuwantowej chemioterapii i.v. [76]. Wydaje się celowe, aby szczegółowo opisywać parametry cewników i obserwować wyniki chemioterapii drogą IP, ponieważ daje to szansę zapobieżenia powikłaniom i zapewni dalszy rozwój tej dziedziny chemioterapii. Wskazane byłoby stworzenie w Polsce protokołu chemioterapii dootrzewnowej oraz chemioterapii dootrzewnowej w hipertermii, które zaaprobowałoby towarzystwa onkologiczne, a także wypracowanie systemu monitorowania powikłań leczenia. Obserwacje ośrodków z dużym doświadczeniem pokazują, że leczenie IPC (oraz HIPEC) powinno być prowadzone tam, gdzie jest możliwe zapewnienie odpowiedniego zaplecza onkologicznego oprócz możliwości technicznych właściwie funkcjonujący oddział chemioterapii oraz wykwalifikowany i doświadczony personel.

\author{
Dr Marcin Śniadecki \\ Katedra i Klinika Ginekologii, Ginekologii Onkologicznej \\ i Endokrynologii Ginekologicznej \\ Gdański Uniwersytet Medyczny \\ ul. Kliniczna 1A, 80-402 Gdańsk \\ e-mail:marcinsniadecki@gumed.edu.pl
}

Otrzymano: 2 listopada $2012 \mathrm{r}$.

Przyjęto do druku: 29 stycznia 2013 r. 


\section{Piśmiennictwo}

1. Lichtenberg HW. Zur intraperitonealen Chemotherapie mit Ladogal. Bruns Beitr Klin Chir 1953; 186: 158-171.

2. Wiesberger AS, Levine B, Storaasli JP. Use of nitrogen mustard in treatment of serous effusions of neoplastic origin. JAMA 1955; 1704-1707.

3. Armstrong DK, Bundy B, Wenzel L i wsp. Gynecologic Oncology Group. Intraperitoneal cisplatin and paclitaxel in ovarian cancer. N Engl J Med 2006; 354: 34-43.

4. Airley R. Cancer Chemotherapy. Basic Science to the Clinic. W: Airley R. Timing of Chemotherapy. Wiley-Blackwell 2009: 55-59.

5. Hamilton CA, Berek SA. Intraperitoneal chemotherapy for ovarian cancer. Curr Opin Oncol 2006; 18: 507-515.

6. Glehen O, Kwiatkowski F, Sugarbaker PH i wsp. Cytoreductive surgery combined with perioperative intraperitoneal chemotherapy for the management of peritoneal carcinomatosis from colorectal cancer: a multi-institutional study. J Clin Oncol 2004; 22: 3284-3292.

7. Piccart MJ, Floquet A, Scarfone i wsp. Intraperitoneal cisplatin versus no further treatment: 8 year results of EORTC 55875, a randomized phase III study in ovarian cancer patients with a pathologically complete remission after platinum-based intravenous chemotherapy. Int J Gynecol Oncol 2003; 13 (suppl. 2): 196-203.

8. Schomas DA, Miller RC, Donohue JH i wsp. Intraperitoneal treatment for peritoneal mucinous carcinomatosis of appendiceal origin after operative management: long-term follow-up of the Mayo Clinic experience. Ann Surg 2009; 249: 588-595.

9. Glehen O, Schreiber V, Cotte E i wsp. Cytoreductive surgery and intraperitoneal chemohyperthermia for peritoneal carcinomatosis arising from gastric cancer. Arch Surg 2004; 139: 20-26.

10. Jaaback K, Johnson N, Lawrie TA. Intraperitoneal chemotherapy for the initial management of primary epithelial ovarian cancer. Cochrane Database Syst Rev 2011 9; 11: CD005340.

11. Galaal K, Naik R, Bristow RE i wsp. Cytoreductive surgery plus chemotherapy versus chemotherapy alone for recurrent epithelial ovarian cancer. Cochrane Database of Systematic Reviews 2010, Issue 6. Art. No.: CD007822. DOI: 10.1002/14651858.CD007822.pub2.

12. Glehen O, Gilly FN, Boutitie F i wsp; French Surgical Association. Toward curative treatment of peritoneal carcinomatosis from nonovarian origin by cytoreductive surgery combined with perioperative intraperitoneal chemotherapy: a multi-institutional study of 1,290 patients. Cancer 2010; 116: 5608-5618.

13. Deroose JP, Eggermont AM, van Geel AN i wsp. Long-term results of tumor necrosis factor alpha- and melphalan-based isolated limb perfusion in locally advanced extremity soft tissue sarcomas. J Clin Oncol 2011; 29: 4036-4044.

14. Barry KG, Shambaugh GE, Goler D. A new flexible cannula and seal to provide prolonged access to the peritoneal cavity for dialysis, drainage and other procedures. J Urol 1963; 90: 125-128.

15. Tenckhoff $\mathrm{H}$, Schechter $\mathrm{H}$. A bacteriologically safe peritoneal access device. Trans Am Soc Artif Intern Organs 1968; 14: 181-187.

16. Dedrick RL, Myers CE, Bungay PM i wsp. Pharmacokinetic rationale for peritoneal drug administration in the treatment of ovarian cancer. Cancer Treat Rep 1978; 62: 1-11.

17. Jones RB, Myers CE, Guarino AM i wsp. High volume intraperitoneal chemotherapy ("belly bath") for ovarian cancer. Pharmacologic basis and early results. Cancer Chemother Pharmacol 1978; 3: 161-166.

18. Speyer JL, Collins JM, Dedrick RL i wsp. Phase I and pharmacological studies of 5-fluorouracil administered intraperitoneally. Cancer Res 1980; 40: 567-572

19. Markman M, Rowinsky E, Hakes Ti iwsp. Phase I trial of intraperitoneal taxol: a Gynecologic Oncology Group Study. J Clin Oncol 1992; 10: 1485-1491.

20. Alberts DS, Liu PY, Hannigan EV i wsp. Intraperitoneal cisplatin plus intravenous cyclophosphamide versus intravenous cisplatin plus intravenous cyclophoshamide for stage III ovarian cancer. N Engl J Med 1996; 335: 1950-1955.

21. Markman M, Berek JS, Blessing JA i wsp. Characteristics of patients with small-volume residual ovarian cancer unresponsive to cisplatin-based ip chemotherapy: lessons learned from a Gynecologic Oncology Group phase II trial of ip cisplatin and recombinant alpha-interferon. Gynecol Oncol 1992; 45: 1-2.

22. Walker JL, Armstrong DK, Huang HQ i wsp. Intraperitoneal catheter outcomes in a phase III trial of intravenous versus intraperitoneal chemotherapy in optimal stage III ovarian and primary peritoneal cancer: a Gynecologic Oncology Group Study. Gynecol Oncol 2006; 100: 27-32.
23. Jaaback K, Johnson N, Lawrie TA. Intraperitoneal chemotherapy for the initial management of primary epithelial ovarian cancer. Cochrane Database Syst Rev 2011 9; 11: CD005340.

24. Kirmani S, Braly PS, McClay EF. A comparison of intravenous versus intraperitoneal chemotherapy for the initial treatment of ovarian cancer. Gynecol Oncol 1994; 54: 338-344.

25. Yen MS, Juang CM, Lai CR i wsp. Intraperitoneal cisplatin-based chemotherapy vs. intravenous cisplatin-based chemotherapy for stage III optimally cytoreduced epithelial ovarian cancer. Int J Gynaecol Obstet 2001; 72: 55-60.

26. Zylberberg B, Ravina JH, Salat-Baroux J i wsp. Polychemotherapy of ovarian cancer via combined intravenous and intraperitoneal routes. Technic and preliminary results. J Gynecol Obstet Biol Reprod (Paris) 1986; 15: 671-676.

27. Polyzos A, Tsavaris N, Kosmas C i wsp. A comparative study of intraperitoneal carboplatin versus intravenous carboplatin with intravenous cyclophosphamide in both arms as initial chemotherapy for stage III ovarian cancer. Oncology 1999; 56: 291-296.

28. Gaducci A, Carnino F, Chiara S i wsp. Intraperitoneal versus intravenous cisplatin in combination with intravenous cyclophosphamide and epidoxorubicin in optimally cytoreduced advanced epithelial ovarian cancer: a randomized trial of the Gruppo Oncologico Nord-Ovest. Gynecol Oncol 2000; 76: 157-162.

29. Markman M, Bundy BN, Alberts DS i wsp. Phase III trial of standard-dose intravenous cisplatin plus paclitaxel versus moderately high-dose carboplatin followed by intravenous paclitaxel and intraperitoneal cisplatin in small-volume stage III ovarian carcinoma: an intergroup study of the Gynecologic Oncology Group, Southwestern Oncology Group, and Eastern Cooperative Oncology Group. J Clin Oncol 2001; 19: 1001-1007.

30. Young RC, Brady MF, Nieberg RK i wsp. Adjuvant treatment for early ovarian cancer: a randomized phase III trial of intraperitoneal 32P or intravenous cyclophosphamide and cisplatin - a gynecologic oncology group study. J Clin Oncol 2003; 23: 4350-4355.

31. National Cancer Institute. Clinical announcement, January 5, 2006. Dostępne: http://www.cancer.gov/newscenter/pressreleases/IPchemotherapy. Dostęp: październik 2012.

32. www.nccn.org/professionals/physician_gls/pdf/ovarian.pdf.

33. Fujiwara K, Aotani E, Hamano T i wsp. A randomized Phase II/III trial of 3 weekly intraperitoneal versus intravenous carboplatin in combination with intravenous weekly dose-dense paclitaxel for newly diagnosed ovarian, fallopian tube and primary peritoneal cancer. Jpn J Clin Oncol 2011; 41: 278-282.

34. Bristow RE, Tomacruz RS, Armstrong DK i wsp. Survival effect of maximal cytoreductive surgery for advanced ovarian carcinoma during the platinum era: a meta-analysis. J Clin Oncol 2002; 20: 1248-1259.

35. Stamm O, Bigler R. Prolonged intraperitoneal chemotherapy of ovarian tumors with Endoxan. Gynaecologia 1968; 165: 90-95.

36. Markman M, Reichman B, Hakes T i wsp. Evidence supporting the superiority of intraperitoneal cisplatin compared to intraperitoneal carboplatin for salvage therapy of small-volume residual ovarian cancer. Gynecol Oncol 1993; 50: 100-104.

37. Morgan RJ Jr, Doroshow JH, Synold T i wsp. Phase I trial of intraperitoneal docetaxel in the treatment of advanced malignancies primarily confined to the peritoneal cavity: dose-limiting toxicity and pharmacokinetics. Clin Cancer Res 2003; 9: 5896-5901.

38. Chemotherapy for advanced ovarian cancer. Advanced Ovarian Cancer Trialists Group. Cochrane Database Syst Rev 2000; (2): CD001418.

39. Los G, Verdegaal EM, Mutsaers PH i wsp. Penetration of carboplatin and cisplatin into rat peritoneal tumor nodules after intraperitoneal chemotherapy. Cancer Chemother Pharmacol 1991; 28: 159-165.

40. 40. du Bois A, Lück HJ, Meier W i wsp. A randomized clinical trial of cisplatin/paclitaxel versus carboplatin/paclitaxel as first-line treatment of ovarian cancer. J Natl Cancer Inst. 2003; 95: 1320-1329.

41. Höckel M. Cancer permeates locally within ontogenic compartments: clinical evidence and implications for cancer surgery. Future Oncol 2012; 8: 29-36.

42. Sugarbaker PH. Surgical management of peritoneal carcinosis: diagnosis, prevention and treatment. Langenbecks Arch Chir 1998; 373: 189-196.

43. Deraco M, Baratti D, Kusamura S i wsp. Surgical technique of parietal and visceral peritonectomy for peritoneal surface malignancies. J Surg Oncol 2009; 100: 321-328. 
44. Verwaal VJ, Bruin S, Boot H i wsp. 8-year follow-up of randomized trial: cytoreduction and hyperthermic intraperitoneal chemotherapy versus systemic chemotherapy in patients with peritoneal carcinomatosis of colorectal cancer. Ann Surg Oncol 2008; 15: 2426-2432.

45. Walker JL, Armstrong DK, Huang $\mathrm{HQ}$ i wsp. Intraperitoneal catheter outcomes in a phase III trial of intravenous versus intraperitoneal chemotherapy in optimal stage III ovarian and primary peritoneal cancer: a Gynecologic Oncology Group Study. Gynecol Oncol 2006; 100: 27-32.

46. Makhija S, Leitao M, Sabbatini P i wsp. Complications associated with intraperitoneal chemotherapy catheters. Gynecol Oncol 2001; 81:77-81.

47. Helm CW. Ports and complications for intraperitoneal chemotherapy delivery. BJOG 2012; 119: 150-159.

48. Robinson WR, Beyer J. Factors affecting the completion of intraperitoneal chemotherapy in women with ovarian cancer. Int J Gynecol Cancer 2010; 20: 70-74.

49. Piccart MJ, Speyer JL, Markman M i wsp. Intraperitoneal therapy: technical experience at five institutions. Semin Oncol 1985; 12: 90-96.

50. MilczekT, Emerich J, Klasa-Mazurkiewicz D. Surgical complications connected with intraperitoneal chemotherapy in ovarian cancer. Ginekol Pol 2003: 74: 817-823.

51. Landrum LM, Gold MA, Moore KN i wsp. Intraperitoneal chemotherapy for patients with advanced epithelial ovarian cancer: a review of complications and completion rates. Gynecol Oncol 2008; 108: 342-347.

52. Sakuragi N, Nakajima A, Nomura E i wsp. Complications relating to intraperitoneal administration of cisplatin for ovarian carcinoma. Gynecol Oncol 2000; 79: 420-423.

53. Helm CW. Technique of intraperitnoeal chemotherapy: normothermic and hyperthermic. W: Ayhan A, Reed N, Gultekin M i wsp. (red.). Textbook of gynecological oncology. Günes Publishing 2012; p. 785.

54. Bège $T$, Lelong $B$, Viret $F$ i wsp. Bevacizumab-related surgical site complication despite primary tumor resection in colorectal cancer patients. Ann Surg Oncol 2009; 16: 856-860.

55. Deshaies I, Malka D, Soria JC i wsp. Antiangiogenic agents and late anastomotic complications. J Surg Oncol 2010; 101: 180-183.

56. von Gruenigen VE, Huang HQ, Gil KM i wsp. The association between quality of life domains and overall survival in ovarian cancer patients during adjuvant chemotherapy: a Gynecologic Oncology Group Study. Gynecol Oncol 2012; 124: 379-382.

57. 57. Lesnock JL, Richard SD, Zorn KK i wsp. Completion of intraperitoneal chemotherapy in advanced ovarian cancer and catheter-related complications. Gynecol Oncol 2010; 116: 345-350.

58. Bristow RE, Santillan A, Salani R i wsp. Intraperitoneal cisplatin and paclitaxel versus intravenous carboplatin and paclitaxel chemotherapy for Stage III ovarian cancer: a cost-effectiveness analysis. Gynecol Oncol 2007; 106: 476-481.

59. Bristow RE, Santillan A, Diaz-Montes TP i wsp. Centralization of care for patients with advanced-stage ovarian cancer: a cost-effectiveness analysis. Cancer 2007; 109: 1513-1522.

60. Havrilesky LJ, Secord AA, Darcy KM i wsp; Gynecologic Oncology Group. Cost effectiveness of intraperitoneal compared with intravenous chemotherapy for women with optimally resected stage III ovarian cancer: a Gynecologic Oncology Group study. J Clin Oncol 2008; 26:4144-4150.
61. Vaupel PW, Kelleher DK. Metabolic status and reaction to heat of normal and tumor tissue. W: Seegenschmiedt MH, Fessenden P, Vernon CC (red) Thermo-radiotherapy and thermo-chemotherap. Biology, physiology and physics. Vol 1: 157-176.

62. van der Zee J, González González D, van Rhoon GC i wsp. Comparison of radiotherapy alone with radiotherapy plus hyperthermia in locally advanced pelvic tumours: a prospective, randomised, multicentre trial. Dutch Deep Hyperthermia Group. Lancet 2000; 9210: 1119-1125.

63. Lutgens L, van der Zee J, Pijls-Johannesma M i wsp. Combined use of hyperthermia and radiation therapy for treating locally advanced cervix carcinoma. Cochrane Database Syst Rev 2010; 17: CD006377.

64. Vernon CC, Hand JW, Field SB i wsp. Radiotherapy with or without hyperthermia in the treatment of superficial localized breast cancer: results from five randomized controlled trials. International Collaborative Hyperthermia Group. Int J Radiat Oncol Biol Phys 1996; 35: 731-744.

65. Van Der Zee J, De Bruijne M, Mens JW i wsp. Reirradiation combined with hyperthermia in breast cancer recurrences: overview of experience in Erasmus MC. Int J Hyperthermia 2010; 26: 638-648.

66. Helm CW, Bristow RE, Kusamura Si wsp. Hyperthermic intraperitoneal chemotherapy with and without cytoreductive surgery for epithelial ovarian cancer. J Surg Oncol 2008; 98: 283-290.

67. Pfannenberg C, Königsrainer I, Aschoff P i wsp. (18)F-FDG-PET/CT to select patients with peritoneal carcinomatosis for cytoreductive surgery and hyperthermic intraperitoneal chemotherapy. Ann Surg Oncol 2009; 16: 1295-1303.

68. Dovern $\mathrm{E}$, de Hingh IH, Verwaal VJ i wsp. Hyperthermic intraperitoneal chemotherapy added to the treatment of ovarian cancer. A review of achieved results and complications. Eur J Gynecol Oncol 2010; 31 256-261.

69. Cotte E, Glehen O, Mohamed F i wsp. Cytoreductive surgery and intraperitoneal chemo-hyperthermia for chemo-resistant and recurrent advanced epithelial ovarian cancer: prospective study of 81 patients. World J Surg 2007; 31: 1813-1820.

70. Glockzin G, Renner P, Popp FC i wsp. Hepatobiliary procedures in patients undergoing cytoreductive surgery and hyperthermic intraperitoneal chemotherapy. Ann Surg Oncol 2011; 18: 1052-1059.

71. Wust $\mathrm{P}$, Hildebrandt B, Sreenivasa G i wsp. Hyperthermia in combined treatment of cancer. Lancet Oncol 2002; 8: 487-497.

72. Baumann K, Pfisterer J, Wimberger P i wsp. Intraperitoneal treatmen with the trifunctional bispecific antibody Catumaxomab in patients with platinum-resistant epithelial ovarian cancer: a phase lla study of the AGO Study Group. Gynecol Oncol 2011; 123: 27-32.

73. Facy O, Radais F, Ladoire S i wsp. Comparison of hyperthermia and adrenaline to enhance the intratumoral accumulation of cisplatin in a murine model of peritoneal carcinomatosis. J Exp Clin Cancer Res 2011; 30: 4

74. Ramarajapalli ML, Kilara NG, Subramanyam M i wsp. Technique of intraperitoneal chemotherapy using Veress needle in patients with ovarian cancer. Int J Gynecol Cancer 2011; 21: 1388-1390.

75. Morrison J, Haldar K, Kehoe S i wsp. Chemotherapy versus surgery for initial treatment in advanced ovarian epithelial cancer. Cochrane Database Syst Rev. 2012; 8: CD005343. 